\title{
Simulation Performance of PID Controller for Higher Order System
}

\author{
Puneet Vithal $^{1}$, Pankaj Mohindru², Pooja ${ }^{3}$ \\ Department of Electronic and Communication, Master of Engineering, Punjabi University, Patiala, India ${ }^{1}$ \\ Assistant Professor, Department of Electronic and Communication, Punjabi University, Patiala, India ${ }^{2,3}$
}

\begin{abstract}
The aim of this paper is to do the comparative study of proportional controller, proportional integral controller and conventional PID controller for flowing fluids. In this paper, performance analysis of proportional, proportional integral and conventional PID controller has been done by the use of MATLAB \& SIMULINK and in the end comparison of various times domain parameter is done to prove that the conventional PID controller has small overshoot, settling time, rise time and fast response as compared to P controller and PI controller. PID controller is the most widely used control strategy in industry. The popularity of PID controller can be attributed partly to their robust performance and partly to their functional simplicity. In this paper, the response of the proportional and proportional integral controller is oscillatory which damage the system. The response of the conventional PID controller is free from these dangerous oscillations in transient period. Hence the conventional PID controller is better than proportional and proportional integral controller.
\end{abstract}

Keywords: Z-N tuning, PID controller, PI controller, P controller, Matlab/Simulink.

\section{INTRODUCTION}

It is eminent that more than $95 \%$ of the control loops are PID controller type in process control [5]. The PID controllers are used in wide range of problems like DC motor, Automotive, Air flight control, etc [7]. A PID controller calculates an error value on the basis of difference between measured process variable and desired set point. The controller attempts to minimize the erłb. by adjusting the tuning parameters [4]. These tuning parameters can be interpreted in term of time proportional (P) which depends on the present error, integral (I) which depends on growth of past value and derivative (D) which predicts the future error.

The quality of control in a system depends on settling time, rise time and overshoot values. The effect of increasing the parameters of PID controller is shown in table 1 .

Table I. Effects of Parameters

\begin{tabular}{|c|l|l|l|}
\hline Parameter & $\begin{array}{l}\text { Rise } \\
\text { Time }\end{array}$ & $\begin{array}{l}\text { Settling } \\
\text { Time }\end{array}$ & Overshoot \\
\hline$k_{p}$ & Decrease & $\begin{array}{l}\text { Small } \\
\text { change }\end{array}$ & Increase \\
\hline$k_{i}$ & Decrease & Increase & Increase \\
\hline$k_{d}$ & $\begin{array}{l}\text { Minor } \\
\text { Change }\end{array}$ & Decrease & Decrease \\
\hline
\end{tabular}

The main problem is to optimally reduce such timing parameters, avoiding undesirable overshoot, longer settling times and vibrations. To solve this problem, many authors have been proposed different approaches. Such method requires one closed-loop step set point response experiment similar to the classical Ziegler-Nichols experiment.

\section{PROBLEM FORMULATION}

The aim of this thesis work is to tune a PID controller using Zeigler-Nichols method. The input output transfer function of system is

$$
G(s)=\frac{1}{s^{3}+3 s^{2}+3 s+1}
$$

The transfer function is a third order system with right half plane (RHP) zero. The control objective is to keep the various performance specifications such as rise time $t_{r}$, settling time $t_{s}$, maximum percentage overshoot $M_{p}(\%)$, maximum percentage undershoot $\mathrm{M}_{\mathrm{u}}(\%)$ and steady state error within desirable limits. But several industrial processes have the "dead-time effect" produced due to measurement of time delay or due to the approximation of higher order dynamics of the process by a simple transfer function model. This time delay degrades the stability of the whole system.

\section{TUNING OF PID CONTROLLER USING SIMULATION}

Simulation results are obtained using MATLAB for the higher order transfer function which is used in the cases of conventional PID.

$$
G(s)=\frac{1}{s^{3}+3 s^{2}+3 s+1}
$$

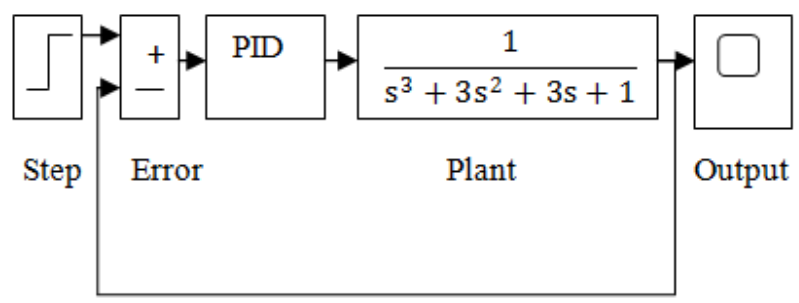

Fig.1. Plant with PID controller 
Fig.1 shows the block diagram of PID controller. The The value of Ziegler-Nichols tuning parameters for difference between the step and output feedback passed as proportional controller are $\mathrm{K}_{\mathrm{p}}=0.5 * \mathrm{~K}_{\mathrm{u}}=4$, It is also noted input into PID controller block. Such block contains that overshoot $\mathrm{M}_{\mathrm{p}}=54.3 \%$, Rise time $\left(\mathrm{t}_{\mathrm{r}}\right)=0.964 \mathrm{sec}$ and MATLAB functions which implement the tuning formula. Settling time $\left(t_{s}\right)=18.7 \mathrm{sec}$. Response of the system when PID tool box is used to tune the PID controller which may improve the performance of higher order system.

\section{TUNING OF P, PI \& PID CONTROLLER WITH ZEIGLER-NICHOLS METHOD}

Tuning of conventional controller has been done by the Ziegler-Nichols method which is mostly used in industrial PID tuning. Routh's stability criterion method is used to determine the initial value of $K_{p}, K_{i}$ and $K_{d}$.

Table II. Ziegler-Nichols tuning method.

\begin{tabular}{|c|c|c|c|}
\hline $\begin{array}{c}\text { Control } \\
\text { Type }\end{array}$ & $\mathbf{K}_{\mathbf{p}}$ & $\mathbf{K}_{\mathbf{i}}$ & $\mathbf{K}_{\mathbf{d}}$ \\
\hline $\mathrm{P}$ & $0.5^{*} \mathrm{~K}_{\mathrm{p}}$ & $\infty$ & 0 \\
\hline $\mathrm{PI}$ & $0.45^{*} \mathrm{~K}_{\mathrm{p}}$ & $1.2^{*} \mathrm{~K}_{\mathrm{p}} / \mathrm{T}_{\mathrm{u}}$ & 0 \\
\hline $\mathrm{PID}$ & $0.6^{*} \mathrm{~K}_{\mathrm{p}}$ & $2 * \mathrm{~K}_{\mathrm{p}} / \mathrm{T}_{\mathrm{u}}$ & $\begin{array}{c}\mathrm{K}_{\mathrm{p}} * \\
\mathrm{~T}_{\mathrm{u}} / 8\end{array}$ \\
\hline
\end{tabular}

The frequency response method as suggested by ZieglerNichols is applied for design of PID controller. By setting $\mathrm{T}_{\mathrm{i}}=\infty$ and $\mathrm{T}_{\mathrm{d}}=0$ and using proportional control action $\left(\mathrm{K}_{\mathrm{p}}\right)$ only, the value of gain is increased from 0 to a critical value $K_{u}$ at which the output first exhibits oscillations. $T_{u}$ is known as period of oscillation. The unit step response for different values of gain $\mathrm{K}_{\mathrm{p}}$ were observed. The step response for $K_{p}=8$ is shown in Fig 2 .

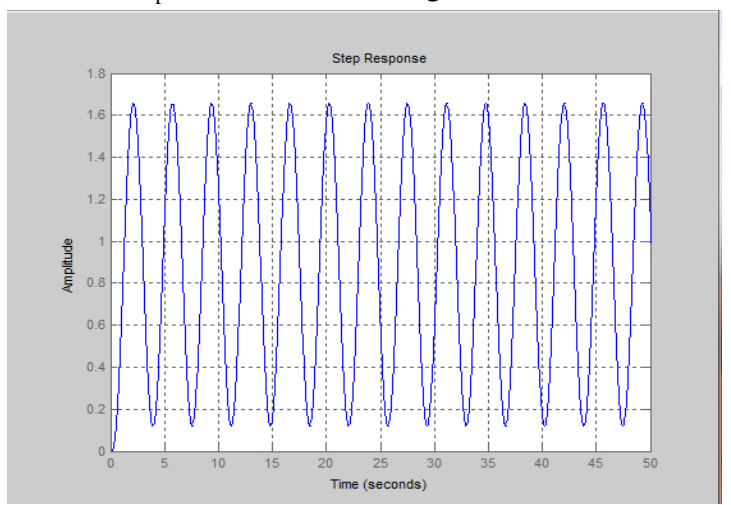

Figure 2. Step response for $\mathrm{K}_{\mathrm{p}}=8$

The above response clearly shows the sustained oscillation occurs at $K_{p}=K_{u}=8$. The period of oscillation $T_{u}$ obtained from the time response is 3.75 .

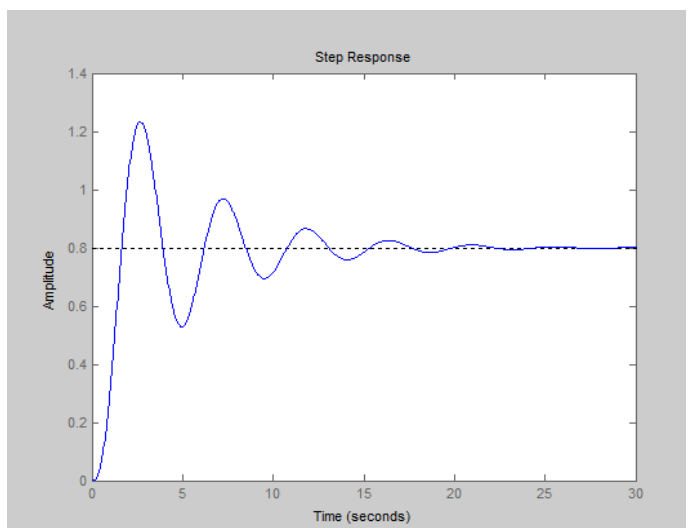

Figure 3. Step response for $K_{p}=4, K_{i}=0, K_{d}=0$ tuning of PI controller is done with Z-N method is shown in Figure 3.

The value of Ziegler-Nichols tuning parameters for Proportional integral controller are $\mathrm{K}_{\mathrm{p}}=0.45 * \mathrm{~K}_{\mathrm{u}}=3.6, \mathrm{~K}_{\mathrm{i}}$ $=1.2 * \mathrm{~K}_{\mathrm{p}} / \mathrm{T}_{\mathrm{i}}=1.152, \mathrm{~K}_{\mathrm{d}}=0$. The unit step response of closed loop system with $\mathrm{K}_{\mathrm{p}}=3.6, \mathrm{~K}_{\mathrm{i}}=1.152, \mathrm{~K}_{\mathrm{d}}=0$ shows that in Figure 4. It is also noted that overshoot $\mathrm{M}_{\mathrm{p}}=$ $54.9 \%$, Rise time $\mathrm{t}_{\mathrm{r}}=1.06 \mathrm{sec}$ and Settling time $\mathrm{t}_{\mathrm{s}}=$ $30.57 \mathrm{sec}$ settling time $\mathrm{t}_{\mathrm{s}}$ are too large.

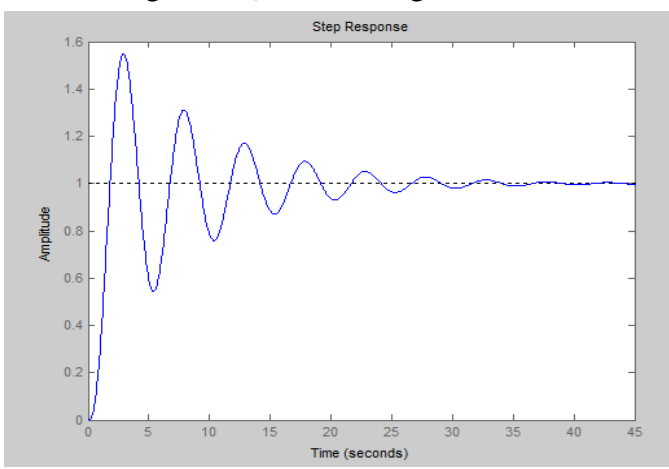

Figure 4. Step response for $\mathrm{K}_{\mathrm{p}}=3.6, \mathrm{~K}_{\mathrm{i}}=1.152, \mathrm{~K}_{\mathrm{d}}=0$

The value of Ziegler-Nichols tuning parameters for PID controller are $\mathrm{K}_{\mathrm{p}}=0.6 * \mathrm{~K}_{\mathrm{u}}=4.8, \mathrm{~K}_{\mathrm{i}}=2 * \mathrm{~K}_{\mathrm{p}} / \mathrm{T}_{\mathrm{u}}=2.56, \mathrm{~K}_{\mathrm{d}}=$ $\left(\mathrm{K}_{\mathrm{p}} * \mathrm{~T}_{\mathrm{d}}\right) / 8=2.25$. The unit step response of closed loop system with $\mathrm{K}_{\mathrm{p}}=4.8, \mathrm{~K}_{\mathrm{i}}=2.56, \mathrm{~K}_{\mathrm{d}}=2.25$ shows that in Figure 5. It is also noted that overshoot $\left(\mathrm{M}_{\mathrm{p})}=38.3 \%\right.$, Rise time $\left(\mathrm{t}_{\mathrm{r}}\right)=0.878 \mathrm{sec}$ and Settling time $\left(\mathrm{t}_{\mathrm{s}}\right)=9.03 \mathrm{sec}$.

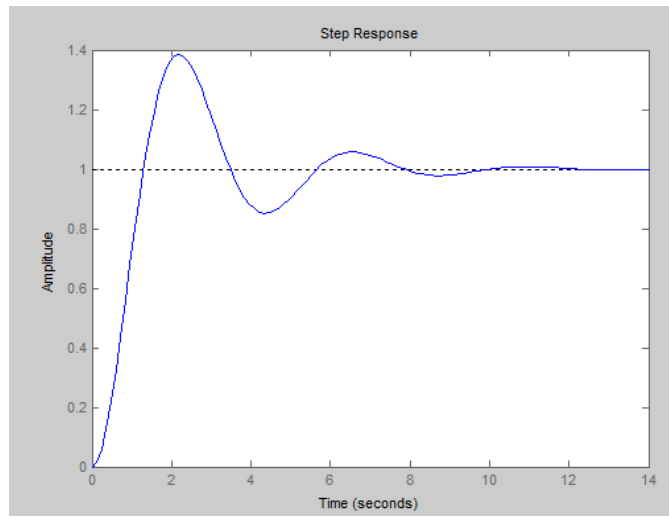

Figure 5. Step response for $K_{p}=4.8, K_{i}=2.56, K_{d}=2.25$.

PID controller gives minimum overshoot $\mathrm{M}_{\mathrm{p}}(\%)$ and much smaller settling time $\left(\mathrm{t}_{\mathrm{s}}\right)$ and rise time $\left(\mathrm{t}_{\mathrm{r}}\right)$, as compared to the P controller and PI controller.

The summary of time response parameters like overshoot $\left(\mathrm{M}_{\mathrm{p}}\right)$,settling time $\left(\mathrm{t}_{\mathrm{s}}\right)$ and rise time $\left(\mathrm{t}_{\mathrm{r}}\right)$ through Ziegler Nichols tuning method for P, PI and PID controllers.

Table III. Time response parameters performance comparison of different controller.

\begin{tabular}{|l|l|l|l|}
\hline Controller/Parameters & $\mathrm{P}$ & $\mathrm{PI}$ & $\mathrm{PID}$ \\
\hline Overshoot $\mathrm{M}_{\mathrm{p}}(\%)$ & 54.3 & 54.9 & 38.3 \\
\hline Rise time $\mathrm{T}_{\mathrm{r}}(\mathrm{sec})$ & 0.964 & 1.06 & 0.878 \\
\hline Settling time $\mathrm{T}_{\mathrm{s}}(\mathrm{sec})$ & 18.7 & 30.5 & 9.03 \\
\hline
\end{tabular}


V.

CONCLUSION

A different kind of techniques is applied to control the higher order system. From the results, shows that PID controller gives excellent performance in all respects. Results using MATLAB/SIMULINK are discussed for Ziegler-Nichols tuning methods for $\mathrm{P}$ controller, PI controller and PID controller. Ziegler-Nichols technique gives higher overshoot $\left(\mathrm{M}_{\mathrm{p}}\right.$ ), rise time $\left(\mathrm{t}_{\mathrm{r}}\right)$ and settling time $\left(\mathrm{t}_{\mathrm{s}}\right)$ in case of $\mathrm{P}$ and PI controller. Initial controller parameters obtained using Z-N tuning formula needs to be adjusted again and again through simulation to get acceptable performances. PID controller gives minimum overshoot $\left(\mathrm{M}_{\mathrm{p}} \%\right)$ and much smaller settling time $\left(\mathrm{t}_{\mathrm{s}}\right)$ and rise time $\left(\mathrm{t}_{\mathrm{r}}\right)$, as compared to the $\mathrm{P}$ controller and PI controller.

\section{REFERENCES}

[1] B. Manke, Linear Control Systems, Hanna Publications, Delhi, 2002.

[2] K. Ogata and Y. Yang, "Modern control engineering," 1970.

[3] A.K. Jairath, "Problem and solutions of control system", CBS Publishers and distributors pvt.ltd, fifth edition, 2010.

[4] Astrom, K.J., and Hagglund, "Automatic tuning of PID controllers"(ISA, 1988).

[5] Ziegler, J.G., and Nichols, N.B "Optimum settings for automatic controllers", Trans. ASME 1942, 64, pp. 759-768.

[6] Valério, D. and Costa, J. S. (2006). "Tuning of fractional PID controllers with Ziegler-Nichols-type rules", Signal Processing, Vol. 86, 2771-2784.

[7] W.K., Hang, C.C, and Cao, L.S, "Tuning of PID controllers based on gain and phase margin specifications", Automatica, 1995, 31, (3), pp. 497-502.

[8] K. Ogata, "Modern Control Engineering", Prentice Hall, New Jersey, 2002.

[9] R. S. Barbosa, J. A. Tenerio, Machado and Isabel. M. Ferreira, "Tuning of PID controllers based Bode"es Ideal transfer function, Nonlinear Dynamics, vol. 38, pp.305- 321, 2004.

[10] Timothy J. Ross, "Fuzzy Logic with engineering applications", WILEY third edition, 2010

[11] Zadeh, L. A., "Fuzzy Sets," Information and Control, Vol. 8, pp. 335-353, 1965.

[12] J.S. Roger Jang, (1997): "Fuzzy Logic Toolbox User's Guide Copyright 1984 - 1997 by the MathWorks", Inc. All Rights Reserved Cheng- Yuan Liou and Yen-Ting Kuo.

[13] Kiam Heong Ang, Gregory Chong and Yun Li, "PID Control System Analysis, Design, and Technology", IEEE Transactions on Control Systems Technology 13(4), pp. 559-576.

[14] J. Paulusova, M. Dubravska, "Application of Design of PID Controller for Continous Systems", IJCSI, Vol7. Issue 5, September 2010.

[15] J. C. Basilio and S. R. Matos, "Design of PI and PID Controllers with Transient Performance Specification", IEEE Transactions on Education, Vol. 45, No. 4, November 2002. 